\title{
Serving Social Justice: The Role of the Commons in Sustainable Food Systems
}

\author{
JENNIFER SUMNER \\ Adult Education and Community Development Program, Ontario Institute for Studies in Education, \\ University of Toronto
}

ABSTRACT Food is a source of sustenance, a cause for celebration, an inducement to temptation, a vehicle for power, an indicator of well-being, a catalyst for change and, above all, a life good. Along with other life goods such as potable water, clean air, adequate shelter and protective clothing, food is something we cannot live without. The global corporate food system, however, allows 800 million to go hungry, while an even larger number of people grow obese. Based in money-values, this food system promotes accumulation first and foremost, enriching a few while creating economic, social and environmental externalities that are destroying local economies, devastating individuals, families and communities and degrading the planet.

What would a food system look like that was based in life-values, centred on the commons and anchored by social justice? This paper will focus on the creation of sustainable food systems, beginning with the crises of the global corporate food system and then moving to the heart of sustainable food systems-the civil commons.

\section{Introduction}

While food represents many things to many people, it has always been a life good or a means of life- that which sustains life. For this reason, food has been at the heart of the human endeavour for millennia. Over the last 50 years, however, it has undergone enormous changes:

Food is no longer viewed first and foremost as a sustainer of life. Rather, to those who seek to command our food supply, it has become instead a major source of corporate cash flow, economic leverage, a form of currency, a tool of international politics, an instrument of power-a weapon! (Krebs cited in Millstone \& Lang, 2003, p. 11)

As food has morphed from a means of life to a blunt instrument of corporate control, it has lost any association it may have had with social justice, leaving in its wake hunger and obesity in equal measure around the world. Both forms of malnutrition, in combination with a wide range of problems associated with industrial agriculture

Correspondence Address: Jennifer Sumner, Ontario Institute for Studies in Education, University of Toronto, Toronto, Ontario, Canada M5S 1V6, Tel.: +1 416978 0784, Email: jennifer.sumner@utoronto.ca

ISSN: 1911-4788 
and an export-based economy, are the inevitable outcomes of a corporate food system that eschews life values and pursues money values at the cost of environmental, social, and economic sustainability.

In the face of the emerging global life-crisis in the realm of food, some argue that the corporate food system is broken (Baker, Campsie, \& Rabinowicz, 2010; Scharf, Levkoe, \& Saul, 2010), while others see it on the road to collapse (Fraser \& Rimas, 2010). Such arguments, in turn, raise questions about an alternative food system. This article will explore the possibilities for a new food system that aims to ensure everyone is fed nutritious food of their choice within the ecological limits of the planet. After discussing social justice and examining the global corporate food system, it will lay out the parameters of an alternative food system based in life values, centred on the civil commons and anchored by social justice.

\section{Social Justice}

Although the term 'social justice' was first used in 1840 by a Sicilian priest in an appeal to the ruling classes to attend to the needs of the new masses of uprooted peasants who had become urban workers (Novak, 2000), it has a much longer history of practice. According to Jackson (1995), the human struggle for social justice is timeless and universal, and can be traced back to Lao-Tzu in China, the slave revolts of ancient Rome, and the Levellers in England. Social justice has been understood by modern scholars as an equitable vision of society, one in which all members are physically and psychologically safe and secure (Adams, Bell, \& Griffin, 1997) or as a process of moving toward equality (Smith, 2000). Power (1999) is more precise when she sees social justice as "a guarantee of an adequate and dignified level of material resources to allow every citizen the stability and security to participate fully in society” (p. 35).

More recently, Basok, Ilcan and Noonan (2006) go beyond Power to define social justice as:

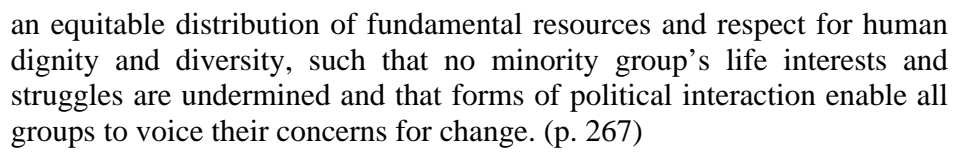
dignity and diversity, such that no minority group's life interests and struggles are undermined and that forms of political interaction enable all groups to voice their concerns for change. (p. 267)

The obverse of social justice is social injustice, which Basok et al. (2006) contend has been growing in the past few decades, as access to resources is increasingly becoming more inequitable and new groups of people have become targets of racism and amplified vigilance due to their identity. Following Basok et al. (2006), we can understand social injustice as an inequitable distribution of fundamental resources and lack of respect for human dignity and diversity, such that minority groups' life interests and struggles are undermined and that forms of political interaction do not enable all groups to voice their concerns for change. Andre Gunder Frank (2002) has probed the question of social injustice, arguing that, at the largest social level, global processes, structures, and institutions seem to generate the greatest injustice. He concluded that there is no end to the issue of social injustice, just as there is no end to the quest and struggle for justice.

Studies in Social Justice, Volume 5, Issue 1, 2011 
Since social justice presupposes life, and life presupposes satisfaction of our liferequirement for food, the food system is absolutely foundational to any socially just society. It is not surprising, then, that many authors have linked social justice specifically to food. For example, Clancy (1994) makes the connection through sustainable agriculture, arguing that "the notion that social justice would be one of the ways in which alternative agriculture would distinguish itself from its conventional counterpart arose in several places, and out of several different sensibilities" (p. 78).

Wekerle (2004) unites social justice and food via food justice movements, using food justice to "highlight the focus on systemic change and the necessity for engaging in political and policy processes as well as consciously addressing issues of movement mobilization and strategies" (p. 379). For Wekerle, such a focus "opens up linkages with a wider range of conceptual frameworks drawn from the literature on democracy, citizenship, social movements, and social and environmental justice" (p. 379).

Allen (2008) unites social justice and food via the food system, arguing there is a lack of social justice in the American agrifood system, as evidenced by prevalent hunger and obesity in low-income populations and exploitation of farm workers. Given that many people seem ready to pay attention to improving the food system, she proposes that, "in a democratic society, the incorporation of social justice priorities and practices must be part of this effort” (p. 157). Using Basok et al.'s definition of social justice, Allen (2008) posits that justice involves three criteria: meeting basic human needs, freedom from exploitation and oppression, and access to opportunity and participation. Applying these three criteria to the food system, she argues that basic needs are not met because "more and more people are going hungry" (p. 157). She finds exploitation occurs throughout the agrifood system, as evidenced by farm workers living in poverty, enduring difficult and dangerous working conditions and lacking housing and health care. In terms of opportunity, she contends that "throughout the world, women are poorer, own less property, do more work, hold less power, are less educated, and suffer more hunger than men” (p. 158). For Allen, it is clear that "our food system does not meet the fundamental criteria of social justice such as freedom from want, freedom from oppression, and access to equal opportunity" (p. 158).

As these authors show, food provides a grounded connection to social justice because "no other public issue is as accessible to people in their daily lives as that of food justice. Everyone - regardless of age, gender, ethnicity, or social class—eats. We are all involved and we are all implicated" (Allen 2008, p. 159).

With this in mind, we can explore food systems as vehicles for social justice or social injustice. We will examine the current global corporate food system and its association with social injustice, and propose a food system based on the commons that can serve social justice.

\section{Food Systems}

According to Kaufman (2004), a food system encompasses a chain of activities that begins with the production of food and moves on to include the processing, distribution, wholesaling, retailing and consumption of food and, eventually, to the 
disposal of food waste. While this linear configuration covers the main components of a food system, it does not convey the idea of a dynamic, interconnected system.

In contrast, Hay (2000) defines a system as a group of elements organized such that one is in some way interdependent (either directly or indirectly) with every other element. We can fruitfully combine these two explanations to define a food system as an interdependent web of activities that include the production, processing, distribution, wholesaling, retailing, consumption and disposal of food. This interdependent web can be very local, as in the self-provisioning of small, isolated groups, or huge, as in the global corporate food system. In terms of scale, however, no food system is inherently just or unjust - that depends on the agenda of those who are empowered by the scalar strategy (see Born \& Purcell, 2006).

\section{Global Corporate Food System}

Following the definition of a food system, the global corporate food system can be understood as an interdependent web of corporate-controlled activities at the global scale that include the production, processing, distribution, wholesaling, retailing, consumption and disposal of food. In his book, Stuffed and Starved, Raj Patel (2007) describes the global corporate food system as "a battlefield” (p. 15), maintaining that it is impossible to think about such a food system without attending to the corporations that have controlled it for centuries, and who crack the supply chain like a whip:

Today, transnational agricultural corporations control 40 per cent of world trade in food, with twenty companies controlling the world coffee trade, six controlling 70 per cent of wheat trade, and one controlling 98 per cent of packaged tea. (pp. 99-100)

This drive for total corporate control of the food system is corroborated by Goodall (2005) who claims that ten multinational corporations control over half the world's food supply. And in the United States, ninety-five percent of the food Americans eat is a corporate product (McMichael, 2000).

Using Allen's (2008) three criteria developed from Basok et al.'s (2006) definition of social justice, we can determine that the global corporate food system denies social justice. First, it does not meet basic human needs. According to McMurtry (1999a) a need for something exists if and only if, and to the extent that, deprivation of it regularly results in an absolute reduction of its owner's life-range capability. This means that, among other things, food is a basic human need, and yet, as Patel (2007) contends, the central problem in the global corporate food system is hunger. In 2004, there were "842 million people suffering from undernourishment in a world that already grows more than enough food to feed the global population" (Ziegler, 2004). By 2010, over 1 billion people are estimated to be undernourished-there are more hungry people than at any time since 1970, the earliest year for which comparable statistics are available (FAO, 2010).

Second, the global corporate food system does not guarantee freedom from exploitation and oppression. For example, the American Planning Association (2007) has outlined the general effects of the global corporate food system on local and

Studies in Social Justice, Volume 5, Issue 1, 2011 
regional areas. It argues that the global corporate food system contributes not only to the increased incidence of obesity and diet-related disease, but also to the loss and erosion of diverse culinary traditions (e.g., First Nations and immigrant cultures). In addition, the APA finds that the global corporate food system is implicated in ecological crises, including extinction of species, declining aquifers and deforestation.

And third, the global corporate food system does not provide access to opportunity and participation. According to the American Planning Association (2007), concentration of ownership in the food system means that decisions affecting communities are increasingly made by absentee business owners. Moreover, to complicate matters, the Association states that government policies may exacerbate this lack of access due to the increasing political influence of food industry giants.

In this way, the global corporate food system does not serve social justice. On the contrary, it is deeply implicated in social injustice and its well-documented "humanspawned social maladies” (Baptiste, 2000, p. 27), which are metastasizing into a global life-crisis of unsustainable proportions-part of what McMurtry (1999a) refers to as the cancer stage of capitalism. Indeed, Fraser and Rimas (2010, p. 164) contend that "Cancerous is exactly the state of our twenty-first-century global food empire."

Can we envision a more sustainable food system-one that meets all three criteria of social justice? To answer this question we need to turn to the heart of sustainability, the civil commons.

\section{Sustainability, Social Justice and the Civil Commons}

Sustainability is a popular term that has become a household word, and part of its popularity rests with its ambiguity. Many have attempted to define it, but none links it to the common life-ground (Sumner, 2005). The concept of the civil commons, however, opens up the possibility of a food system that is life-coherent, sustainable, and just.

Conceptualized by McMurtry (1999b), the civil commons is "any co-operative human construction that protects and/or enables the universal access to life goods" (p. 1). In this way, the civil commons is co-operative, not competitive. It does not occur naturally, but is built by human agency. The civil commons protects through rules and regulations, and enables by opening up spaces and opportunities. It involves universal access, not paid access, to life goods, such as food, water, shelter, education, and healthcare. The civil commons can be described as "society's longevolving system of conscious human protection of the larger life-host humanity lives from" (1999a, p. 213).

Examples of the civil commons are all around us, but have never been collectively named: public education systems, universal health-care programs, building regulations, water and power installations, bridges, social safety protections, laws, libraries, public broadcast media, sewage systems and social assistance. In essence,

The nature of the civil commons can be expressed as follows: It is society's organized and community-funded capacity of universally accessible resources to provide for the life preservation and growth of 
society's members and their environmental life-host. The civil commons is, in other words, what people ensure together as a society to protect and further life, as distinct from money aggregates. (McMurtry 1998, p. 24)

The civil commons is rooted in the life-ground, described by McMurtry (1999a) as including all three planes of life: organic movement, sentience and feeling, and thought: "grounded life-sequence analysis...keeps its eyes on life and its capabilities to think, feel or do, observing whether there is maintenance, growth or decline in these vital fields of being alive” (p. 155).

Given its deep connection to the life-ground and means of life, the civil commons can be seen as foundational to social justice. Johnston (2003, p. 32) makes this clear when she emphasizes that the key point is to "maximize control over the means of subsistence for the ends of maximizing life and social justice-not profits, nor the pursuit of money as an end in itself.” Quoting Naomi Klein's argument that what unites those resisting global capitalist encroachment is a radical reclaiming of the commons, Johnston concludes that "the pressing question for many social justice and environmental activists seems to be less about how we can achieve sustainable development and more about how we can reclaim the commons” (p. 4).

While these social justice and environmental activists do not distinguish between the commons and the civil commons, Johnston (2003) confirms that the two are distinct. In the words of McMurtry (1998):

\footnotetext{
I have introduced the concept of "civil commons" to distinguish it from the traditional "commons"-the shared natural lands upon which an agricultural village economy depends. I mean by the civil commons both the traditional commons and all other universally accessible goods of life that protect or enable the lives of society's members. ... the concept of the civil commons subsumes both the traditional commons and the built commons of universally accessible social goods evolved by public sectors since the Industrial Revolution and, in particular, since the end of World War II. (p. 399)
}

Johnston (2003) notes that "the civil commons tradition is differentiated from the natural commons, or biosphere, so as to make clear that these are cooperative, and distinctly human traditions designed to give access to the means of existence provided by the biosphere" (p. 17). As co-operative human constructions that protect and/or enable universal access to life goods, the many forms of the civil commons are thus recognized as central to social justice.

The civil commons has also been understood as central to sustainability. Succinctly put, sustainability involves a set of structures and processes that build the civil commons (Sumner, 2005). The structures can range from universities, governments and corporations to NGOs, neighbourhood associations and social businesses, as long as they build the civil commons. The processes can include teaching, learning, decision-making, facilitating, governing and researching, as long as they build the civil commons. These structures and processes interact dynamically to create, support and spread the civil commons. The wider and deeper the civil commons-socially, economically and environmentally-the higher the level of sustainability. The more the civil commons is enclosed, the lower the level of

Studies in Social Justice, Volume 5, Issue 1, 2011 
sustainability. In this way, both sustainability and social justice are deeply connected to the civil commons, and all three concepts are central to sustainable food systems.

\section{Sustainable Food Systems}

If sustainability is tightly tied to the civil commons, then moving from the noun "sustainability" to the adjective "sustainable" carries the same meaning. In this way, sustainable development involves development based on the civil commons, not on entrepreneurship initiatives or programs to bring the poor into the global market. Sustainable communities centre on the civil commons, not on economic development or business skills training. Sustainable food systems focus on building the civil commons in the area of food, not on promoting our current cheap food policies or creating new value chains in the global market. Applying the meaning of sustainability to the definition of a food system results in the following:

A sustainable food system involves an interdependent web of activities generated by a set of structures and processes that build the civil commons with respect to the production, processing, distribution, wholesaling, retailing, consumption and disposal of food.... (Sumner, 2010, p. 210)

In other words, to qualify as sustainable, a food system would have to focus on activities that contribute to co-operative human constructs that protect and/or enable universal access to the life good of food.

It follows that a food system in the private sector would preclude sustainability by definition. The fiduciary responsibility of corporations to maximize shareholder return fundamentally conflicts with and even violates the public interest of ensuring that citizens are fed. This incompatibility is emphasized by Michele Simon (2006), a public health attorney, who argues that "under our current economic system it's not a corporation's job to protect public health.” Since a corporation's purview does not include public health, she puts forward the following observations:

Like water (and unlike most other commodities such as toys or electronics), food is indispensable and a basic human right. Why have we turned its production over to private interests? Shouldn't at least some aspects of society remain off-limits to corporate control? (p. 318)

In other words, a sustainable food system must reside in the public domain-a public system in public hands for the public good. Like the Canadian health-care system, a made-in-Canada sustainable food system would be supported by four pillars: universality, accessibility, portability and public administration. Based on a single payer, we would all contribute so everyone could eat. And following in the image of natural cycles, it would close loops as tightly as possible, so that positive synergies could be achieved.

Unlike the global corporate food system, a sustainable food system would highlight the role of farmers: they would be recognized for their knowledge and rewarded for their work. Processing would not involve large, centralized facilities that skim profits from the value chain, but regional operations organized as worker co-operatives. Distributors would connect the nodes of the regional system, not 
lobby for global reach. Wholesalers would facilitate distribution to everyone, not skim off profits for themselves. Retailers would offer wholesome, nutritious food, not profit from obesity by selling "pseudo-foods" (Winson, 2004, p. 302) laden with salt, sugar, and oil. Consumers would obtain local food or fair-trade global food from social businesses, co-operatives, food clubs, community food centres or food banks (in the true sense of the term-where food surplus is stored), not supermarkets that specialize in faceless, placeless, unfair food. And all participants in the food system would compost waste either for personal use or for municipal depots that would recycle it back to farms.

\section{Sustainable Food Systems and Social Justice}

In his work on regenerative or sustainable food systems, Dahlberg (1993) stressed the "Es"- ecology, ethics, and equity:

(1) Sustainability as long-term food sufficiency, i.e., food systems that are more ecologically based and that do not destroy their natural resource base. (2) Sustainability as stewardship, i.e., food systems that are based on a conscious ethic regarding humankind's relationship to other species and to future generations. (3) Sustainability as community, i.e., food systems that are equitable or socially just. (p. 81)

However, it is arguable whether any food system has ever promoted social justice. In his study of past civilizations, Wright (2004) contends that agriculture has seldom solved the food problem because of two inevitable (or nearly inevitable) consequences:

The first is biological: the population grows until it hits the bounds of the food supply. The second is social: all civilizations become hierarchical; the upward concentration of wealth ensures that there can never be enough to go around. (p. 108)

Arguable exceptions to food system injustice include Plains Indian tribes before European conquest or present-day Cuba, with its rations of rice and beans and its flourishing urban agriculture providing free or low-cost vegetables. Another exception is the city of Belo Horizonte, Brazil, which declared food to be a right and developed dozens of innovations to assure everyone the right to food-including offering farmers choice spots of public space from which to sell to urban consumers, low-priced food markets on city property and People's Restaurants that serve meals for the equivalent of less than 50 cents (Lappé, 2009).

Generally speaking, however, food has long been about wealth as well as power (Friedmann, 1993) and as such, food systems have not generally been known as vehicles for social justice. The global corporate food system is just the current conveyance on a long road of social injustice with respect to food. Hunger, undernutrition, undernourishment, chronic hunger, malnutrition and food insecurity have been the hallmarks of most food systems from the beginnings of agriculture to the present day.

Studies in Social Justice, Volume 5, Issue 1, 2011 
That said, a food system that promotes social justice is not impossible. In the words of Albritton (2009), "we would like to see a world in which every woman, man and child could access sufficient nutritious food in an environment that encourages healthy eating and that produces the food in ecologically sustainable ways” (p. 122). Following Allen's (2008) criteria developed from Basok et al.'s (2006) definition of social justice, we can outline the parameters of a food system that promotes social justice.

\section{Meeting Basic Human Needs}

Since food is a basic human need, the central focus of a sustainable food system would be the equitable distribution of nutritious food to everyone in the system, within planetary limits. This would mean establishing clear resource and environmental limits (see Jackson, 2009) and working within them. It would also mean not only remedying the problem that the minority of the world's populationthe so-called developed world-uses most of the resources, but also dealing with the scale of the global population in general. According to Jackson (2009), "the fastest population growth has occurred in the developing world — driven . . by a lack of education and inadequate access to contraception" (p. 77). A civil-commons approach to development, led by a sustainable food system and backed by free, universal systems of education (including sex education) and healthcare (including widely available birth control) would help to address both of Wright's (2004) arguments about the "inevitable" consequences of agriculture.

In a sustainable food system, food would no longer be an opportunity for private enrichment, an instrument of power or a weapon to force compliance. Instead, it would be the keystone of a system that ensured everyone was fed. Food would be understood as a public resource to be stewarded, renewed and shared. In terms of stewardship, food waste in the system would be reduced and land on which to grow food would be protected as a vital resource. With respect to renewal, food would be grown organically, which builds up soils and eschews harmful synthetic pesticides and fertilizers. On the subject of sharing, food would be distributed equitably. Food banks would develop stockpiles in times of plenty and divide up supplies in times of famine.

\section{Freedom from Exploitation and Oppression}

The power of food has long been associated with the accumulation of agricultural surplus - who owns it or controls it. As a public resource, food would lose this association and be understood as a collective good—owned by all and controlled by everyone.

As food becomes disassociated with power, the ability to exploit and oppress people diminishes in a number of ways. First, like universal healthcare, a universal food system would relieve people of the fear of lacking one of the basic needs of life. No longer threatened with hunger, people would be freer to make productive choices regarding their future. And in a time of looming scarcity in fossil fuels (the basis of the global corporate food system's fertilizers, pesticides and long-distance trade), 
increasing natural disasters, endless wars for ever-scarcer resources and unstable climate conditions, policies to develop sustainable food systems will address questions of food security.

Second, cheap food policies as currently conceived would be eliminated. Such policies have bankrupted farmers and destroyed farmland, but have been implemented to reduce the need to raise the minimum wage. As Pollan (2010) explains,

\begin{abstract}
...instead of paying workers well enough to allow them to buy things like cars, as Henry Ford proposed to do, companies like Wal-Mart and McDonald's pay their workers so poorly that they can afford only the cheap, low-quality food these companies sell, creating a kind of nonvirtuous circle driving down both wages and the quality of food. The advent of fast food (and cheap food in general) has in effect, subsidized the decline of family incomes in America. (p. 2)
\end{abstract}

Instead of being out of reach of the lowest income earners, nutritious food would be subsidized by taxes on pseudo-foods. In this way, inexpensive pseudo-foods would no longer be the only choice for cash-strapped families, thus reversing the growing obesity epidemic and its related medical problems.

Third, workers in the food system would no longer be exploited. According to Albritton (2009), food is among the most labour-intensive of all commodities. He argues that the final consumer in most instances is unaware of the exploitation of labour that occurs at almost every step in the food chain from field to table. In our technologically sophisticated capitalist economy, "food chain workers are among the most exploited, the most impoverished and the most exposed to hazardous chemicals" (p. 144). Instead of such exploitation, he suggests that all those participating in the food chain be well paid as a reward for their important and often very demanding work.

And fourth, food deserts would cease to exist. Lister (2007) has described a food desert as "large gaps in the city where it is difficult or impossible to find a grocery store or supermarket within walking distance, and where the predominant means to buy food is through fast-food outlets and higher-priced convenience stores” (p. 169). The problem with food deserts is graphically described by a Chicago food activist:

In my neighbourhood, I can buy designer gym shoes, every kind of fast food, junk food, all kinds of malt liquor, illegal drugs, and maybe even a semiautomatic weapon. But I cannot purchase an organic tomato. (Redmond in Metcalf Foundation, 2008, p. 17)

The nodes of a sustainable food system would be arranged in such a way that food deserts would be phased out and all income levels would be able to obtain nutritious food of their choice, within planetary limits.

Studies in Social Justice, Volume 5, Issue 1, 2011 


\section{Access to Opportunity and Participation}

A sustainable food system would open up access to opportunity and participation for producers, workers and consumers. Producers would not be tied to artificially low global market prices which force them to mine the soil just to service their debts. Instead, they would be paid a living wage for their valuable contributions to vital life needs - food production and ecological services. Producers would also develop or join co-operatives-civil commons constructs that would help them become more socially, environmentally and economically sustainable.

Workers in a sustainable food system would also develop or join unions or co-ops. In this way, they would learn valuable social and economic skills by being part of a horizontal commons structure, instead of remaining voiceless in minimum-wage, dead-end jobs at the bottom of the food hierarchy. For example, workers would democratically participate in the decisions that affected their working conditions. In this way, slave labour, unsafe working conditions and unequal pay - all in the name of food production and provision - would be relegated to the past.

In a sustainable food system, consumers would no longer be faced with the illusion of abundance in grocery stores, which masks their lack of opportunity and participation in the global corporate food system. Instead of the corporate mantra of "consumer choice" and the reality of little input regarding the range and quality of food offered, they would gain some control through consumer co-ops and neighbourhood social businesses specializing in food. This is in stark contrast to current conditions where high profit margins drive food retailers to dedicate an average of $31 \%$ of their shelf space to pseudo-foods and -beverages (Winson, 2004). Healthier food choices are exiled to the outer perimeters of the store (Pollan, 2008) or, in the case of organics, ignored until they become a high-profit market niche shorn of the organic philosophy.

In addition, a sustainable food system would provide learning opportunities in the realm of food-healthy food, local food, heritage food and culturally specific food. And like the healthcare system, it would provide a working model to learn from and replicate in other areas of life need, such as water and childcare.

\section{Conclusion}

In his article on sustainable development, Visvanathan (1991) turned the tables on the Brundtland Report-published as Our Common Future-which advocated increased economic growth as the way to reduce poverty and did not contest the prediction of five- to tenfold increase in world industrial output. Instead, he proposed that the path to sustainability lay in our future as a commons.

This paper has taken up Visvanathan's proposal by exploring our future as the civil commons - the heart of sustainability and the route to social justice. In particular, it has examined the role of the civil commons in sustainable food systems. From this examination it is clear that a sustainable food system would be a commons of commons - an overarching co-operative human construction that protects and/or enables universal access to the life good of food. At its best, a sustainable food system would be synonymous with the civil commons - serving social justice as it provided nourishing food to everyone, within the ecological limits of the planet. 


\section{References}

Adams, M., Bell, L.-A., \& Griffin, P. (Eds.). (1997). Teaching for diversity and social justice: A sourcebook. New York, NY: Routledge.

Albritton, R. (2009). Let them eat junk: How capitalism creates hunger and obesity. Winnipeg: Arbeiter Ring Publishing.

Allen, P. (2008). Mining for justice in the food system: Perceptions, practices and possibilities. Agriculture and Human Values, 25, 157-161.

American Planning Association. (2007). Policy guide on community and regional food planning. Retrieved from: http://www.planning.org/policyguides/food.htm.

Baker, L., Campsie, P., \& Rabinowicz, K. (2010). Menu 2020: Ten good ideas for Ontario. Toronto: Metcalf Foundation. Retrieved from: www.metcalffoundation.org

Baptiste, I. (2000). Beyond reason and personal integrity: Toward a pedagogy of coercive restraint. The Canadian Journal for the Study of Adult Education, 14(1), 27-50.

Basok, T., Ilcan, S., \& Noonan, J. (2006). Citizenship, human rights, and social justice. Citizenship Studies, 10(3), 267-273.

Born, B., \& Purcell, M. (2006). Avoiding the local trap: Scale and food systems in planning research. Journal of Planning Education and Research, 26(2), 195-207.

Clancy, K. (1994). Commentary. Social justice and sustainable agriculture: Moving beyond theory. Agriculture and Human Values, 11(4), 77-83.

Dahlberg, K. A. (1993). Regenerative food systems: Broadening the scope and agenda of sustainability. In P. Allen (Ed.), Food for the future: Conditions and contradictions of sustainability (pp. 75-102). New York, NY: John Wiley and Sons, Inc

FAO. (2010). Hunger. Food and Agriculture Organization of the United Nations. Retrieved from http://www.fao.org/hunger/en

Frank, A. G. (2002). A testimonial contribution to the 25th Anniversary issue of Social Justice. Social Justice, 26(2), 51-55.

Fraser, E. D. G., \& Rimas, A. (2010). Empires of food: Feast, famine, and the rise and fall of civilizations. Toronto: Free Press.

Friedmann, H. (1993). After Midas's feast: Alternative food regimes for the future. In P. Allen (Ed.), Food for the future: Conditions and contradictions of sustainability (pp. 213-233). New York, NY: John Wiley and Sons, Inc.

Goodall, J. (2005). Harvest for hope: A guide to mindful eating. New York, NY: Warner Books Inc.

Hay, A. (2000). System. In R.J. Johnston, D. Gregory, G. Pratt \& M. Watts (Eds.), The dictionary of human geography (4th ed., pp. 818-819). Malden, MA: Blackwell Publishers Ltd.

Jackson, T. (1995). Introduction. In David Smith, First Person Plural: A community development approach to social change. Montreal: Black Rose Books.

Jackson, T. (2009). Prosperity without growth: Economics for a finite planet. London/Sterling, VA: Earthscan.

Johnston, J. (2003). Who cares about the commons? Capitalism, Nature, Socialism, 14(4), 1-41.

Kaufman, J. L. (2004). Introduction. Journal of Planning Education and Research, [Special Issue on Planning for Community Food Systems] 23(4), 335-340.

Lappé, F. M. (2009). A visit to Belo Horizonte: The city that ended hunger. Retrieved from http://www.counterpunch.org/lappe03182009.html.

Lister, N.-M. (2007). Placing food: Toronto’s edible landscape. In J. Knechtel, (Ed.), Food (pp. 148-185). Cambridge, MA: MIT Press.

McMichael. P. (2000). The power of food. Agriculture and Human Values, 17, 21-33.

McMurtry, J. (1999a). The cancer stage of capitalism. London: Pluto Press.

McMurtry, J. (1999b, June). The lifeground, the civil commons and global development Paper presented at the annual meeting of the Canadian Association for Studies in International Development, Congress of the Social Sciences and Humanities, Sherbrooke, Quebec.

McMurtry, J. (1998). Unequal freedoms: The global market as an ethical system. Toronto: Garamond.

Metcalf Foundation. (2008). Food connects us all: Sustainable local food in southern Ontario. Retrieved from: www.metcalffoundation.com

Millstone, E. \& Lang, T. (2003). The Penguin atlas of food. New York, NY: Penguin Books.

Novak, M. (2000). Defining social justice. First Things, 108, 11-13.

Patel, R. (2007). Stuffed and starved: Markets, power and the hidden battle for the world's food system. Toronto: HarperCollins Publishers Ltd.

Studies in Social Justice, Volume 5, Issue 1, 2011 
Pollan, M. (2010). The food movement, rising. The New York Review of Books. Retrieved from http://www.nybooks.com/articles/archives/2010/jun/10/food-movement-rising.

Pollan, M. (2008). In defense of food: An eater's manifesto. New York, NY: The Penguin Press.

Power, E., M. (1999). Combining social justice and sustainability for food security. In M. Koc, R. MacRae, L. J.A. Mougeot, \& J. Welsh (Eds.), For hunger-proof cities: Sustainable urban food systems (pp. 30-37). Ottawa: International Development Research Centre.

Scharf, K., Levkoe, C. \& Saul, N. (2010). In every community a place for food: The role of the community food centre in building a local, sustainable, and just food system. Toronto: Metcalf Foundation. Retrieved from: http://www.metcalffoundation.org

Simon, M. (2006). Appetite for profit: How the food industry undermines our health and how to fight back. New York, NY: Nation Books.

Smith, D. M. (2000). Social justice. In R.J. Johnston, D. Gregory, G. Pratt, \& M. Watts (Eds.), The dictionary of human geography (4th ed., pp. 744-759), Malden, MA: Blackwell Publishers Ltd.

Sumner, J. (2010). From land to table: Rural planning and development for sustainable food systems. In D. Douglas (Ed.), Rural Planning and Development in Canada (pp. 179-224). Toronto: Nelson Education Limited.

Sumner, J. (2005). Sustainability and the civil commons: Rural communities in the age of globalization. Toronto: University of Toronto Press.

Visvanathan, S. (1991). Mrs. Bruntland's disenchanted cosmos. Alternatives 16, 377-384.

Wekerle, G. R. (2004). Food justice movements: Policy, planning and networks. Journal of Planning Education and Research, 23, 378-386.

Winson, A. (2004). Bringing political economy into the debate on the obesity epidemic. Agriculture and Human Values, 21, 299-312.

Wright, R. (2004). A short history of progress. Toronto: House of Anansi Press Inc.

Ziegler, J. (2004). The right to food. Report of the Special Rapporteur of the United Nations Commission on Human Rights, submitted to the General Assembly, New York. 